\title{
ENTERIC COLIBACILLOSIS: VACCINATION IN EXPERI- MENTALLY INFECTED EARLY WEANED PIGLETS
}

\author{
J. N. SinGH* AND J. E. TANNER \\ Department of Microbiology, Macdonald College of McGill University, \\ Macdonald College P.O., Quebec, Canada
}

ENTERIC colibacillosis of young swine has been an increasing problem in swine husbandry for many years, especially in relation to modern intensive breeding in continuous farrowing units. The association between certain serotypes of Escherichia coli and this disease has been reviewed at length by Sojka (1965).

Control by the observation of strict hygiene, by the interruption of farrowing periods in the central farrowing unit or by administration of antibiotics has not been fully successful in wiping out infection, although such measures are recommended for arresting outbreaks (Cameron, 1942; Kernkamp and Roepke, 1943; Bunch et al., 1961; Whitehair et al., 1948; Sojka; and Moon, 1969).

Vaccination as a means of protection, by actively immunising the dam or by giving the piglets $E$. coli antisera, has been attempted by several workers with varying and rather conflicting results (Gordon and Luke, 1958; Jones, Sellers and Smith, 1962; Kohler, 1967; Arbuckle, 1968b; Miniats, Mitchell and Barnum, 1970). It should be emphasised that some of the work in this area has involved field trials without adequate controls, and results are therefore difficult to interpret because the strain of $E$. coli used for immunisation may not have been the one that produced the disease.

The aim of the present investigation was to study the efficacy of vaccination in conventionally reared, experimentally infected piglets in which the challenging and immunising strains were identical. Enteropathogenic E. coli strain E145 was used for this purpose since it has been incriminated in several outbreaks of colibacillosis in early weaned piglets of the Macdonald College herd (Chopra, Blackwood and Dale, 1964a). An attempt was also made to correlate the excretion of $E$. coli in faeces with both the production of serum antibody against this organism and diarrhoea. The passive cutaneous anaphylaxis test (PCA) was chosen to detect this antibody since precipitation or agglutination tests yield very low anti-E. coli titres in porcine enteritis (Chopra, Blackwood and Dale, 1964b; Kohler and Bohl, 1966); the more sensitive PCA test was successfully used by Buxton and Thomlinson (1961) to detect antibodies to these organisms.

\section{MATERIALS AND METHODS}

Experimental animals. The four crossbred sows (Landrace $\times$ Yorkshire) used in this investigation were purchased in their late pregnancy. The piglets were kept in farrowing

\footnotetext{
Received 6 Aug. 1971; accepted 2 Sept. 1971.

* Department of Immunology, University of Manitoba, Winnipeg, Manitoba. 
pens with their dams until weaning at 3 wk of age. Each litter was then placed in separate thoroughly cleaned pens. Because of shortage of space, two sows, 1 and 2 , and their offspring were kept in one barn (I), and sows 3 and 4, with their offspring, in another (II). One sow in each barn (sows 1 and 3) was vaccinated with E. coli E145 while sows 2 and 4 were kept as

TABLE I

Outline of the location, distribution and immune state* of the sows and piglets used in the study

\begin{tabular}{|c|c|c|c|c|c|c|c|c|c|c|}
\hline Location & \multicolumn{5}{|c|}{ Barn I } & \multicolumn{5}{|c|}{ Barn II } \\
\hline \multirow[t]{2}{*}{$\begin{array}{c}\text { Test sow and } \\
\text { immunisation state }\end{array}$} & \multicolumn{2}{|c|}{$\underset{V}{\text { Sow } 1}$} & \multicolumn{3}{|c|}{$\begin{array}{l}\text { Sow } 2 \\
\text { NV }\end{array}$} & \multicolumn{2}{|c|}{$\begin{array}{l}\text { Sow } 3 \\
\text { V (FA) }\end{array}$} & \multicolumn{3}{|c|}{$\begin{array}{l}\text { Sow } 4 \\
\text { NV }\end{array}$} \\
\hline & \multicolumn{2}{|c|}{6 piglets } & \multicolumn{3}{|c|}{9 piglets } & \multicolumn{2}{|c|}{6 piglets } & \multicolumn{3}{|c|}{9 piglets } \\
\hline $\begin{array}{l}\text { Litter sample and } \\
\text { immunisation state } \\
\text { of test group }\end{array}$ & $3 \mathrm{~V}$ & $3 \mathrm{NV}$ & $3 \mathrm{~V}$ & $3 \mathrm{NV}$ & $3 \mathrm{NV}$ & $3 \mathrm{~V}(\mathrm{FA})$ & $3 \mathrm{NV}$ & 3V (FA) & $3 \mathrm{NV}$ & $3 P$ \\
\hline Test group letter & A & B & C & D & $F \dagger$ & AA & BB & $\mathrm{CC}$ & DD & $\mathrm{E}$ \\
\hline
\end{tabular}

* $\mathrm{V}=$ Vaccinated; $(\mathrm{FA})=$ Freund's adjuvant used; $\mathrm{NV}=$ non-vaccinated; $\mathbf{P}=$ passively immunised from sow 3 .

$\dagger$ The challenge strain was usually $E$. coli E145, but group F was challenged with strain Mac 111.

TABLE II

E. coli serotypes used in this study

\begin{tabular}{|c|c|c|c|}
\hline $\begin{array}{l}\text { Code } \\
\text { number } \\
\text { of strain }\end{array}$ & Source & Serotype & $\begin{array}{c}\text { Action } \\
\text { on blood }\end{array}$ \\
\hline $\begin{array}{l}\text { E145 } \\
\text { G7 } \\
\text { Mac } 111\end{array}$ & $\begin{array}{l}\text { Weybridge, England* } \\
\text { Weybridge, England* } \\
\text { Isolated from a piglet } \\
\text { with colibacillosis }\end{array}$ & $\begin{array}{c}\text { O141: K85a,c(B) } \\
\text { O8: K87(B)88(L) } \\
?\end{array}$ & $\begin{array}{l}\text { haemolytic } \\
\text { haemolytic } \\
\text { non-haemolytic }\end{array}$ \\
\hline Mac 429 & $\begin{array}{l}\text { Isolated from a piglet } \\
\text { with colibacillosis }\end{array}$ & $?$ & non-haemolytic \\
\hline
\end{tabular}

* These two strains were obtained through the courtesy of Dr W. J. Sojka, The Central Veterinary Laboratory, Weybridge, Surrey.

unvaccinated controls. Six piglets were chosen at random from the litter of each sow for the experimental work. Three piglets of each litter were vaccinated; the other three piglets remained as non-vaccinated controls. Thus four lots of piglets were obtained (i) vaccinated and (ii) non-vaccinated piglets from normal, control sows and (iii) vaccinated and (iv) non-vaccinated piglets from the vaccinated sows. Table I summarises the above information and indicates additional groups used in further studies (q.v.).

Escherichia coli strains. The $E$. coli serotypes used in this investigation are listed in table II. 
E. coli strain E145 was used to vaccinate dams and piglets. E. coli strains E145 and Mac 111 were each used in attempts to induce diarrhoea in early weaned piglets. Antisera were prepared in rabbits against all four $E$. coli strains according to the method of Charter and Taylor (1952) for use in the identification of these organisms in faecal specimens.

Vaccination of sows and piglets. E. coli E145 was grown on trypticase agar (Difco) in Roux flasks for $18 \mathrm{hr}$ at $37^{\circ} \mathrm{C}$. The culture was collected into $10 \mathrm{ml}$ of 0.85 per cent. saline from the surface of the medium in each flask and washed three times with saline. The suspension was then incubated at $4^{\circ} \mathrm{C}$ for $18 \mathrm{hr}$ with 0.5 per cent. formalin $(0.2$ per cent. formaldehyde), and it was then standardised to contain $2 \times 10^{9}$ bacteria per ml.

Sow 1 was given two $5-\mathrm{ml}$ doses of vaccine intramuscularly at an interval of 5 days. The second injection was given 10 days before the sow was due to farrow. Sow 3 received the same dose at the same intervals except that the vaccine was emulsified in an equal volume of Freund's complete adjuvant (Difco).

Piglets were vaccinated intramuscularly $48 \mathrm{hr}$ after birth with $0.2 \mathrm{ml}$ and again 7 days later with $0.5 \mathrm{ml}$ of vaccine. Piglets of group A and group C (offspring of sows 1 and 2 respectively) received the simple formalin-killed vaccine. Piglets of group AA and group CC (offspring of sows 3 and 4 respectively) received the vaccine emulsified in Freund's complete adjuvant (Difco). Piglets of group B and group D (offspring of sows 1 and 2 respectively) and piglets of group $\mathrm{BB}$ and group $\mathrm{DD}$ (offspring of sows 3 and 4 respectively) were not vaccinated.

Piglets of group E (offspring of sow 4) were each immunised passively with $15 \mathrm{ml}$ of immune serum collected from sow 3 and injected subcutaneously $8 \mathrm{hr}$ before the piglets were challenged with $E$. coli E145.

Biochemical and serological identification of $E$. coli in faecal samples. Rectal swabs from sows and piglets were taken every $48 \mathrm{hr}$. Each swab was rotated three times in $10 \mathrm{ml}$ of sterile 0.85 per cent. saline; this saline was then shaken, appropriately diluted and then plated on agar plates containing 5 per cent. sheep blood. A representative number of colonies morphologically resembling $E$. coli was tested for acid and gas production in lactose broth and plated on eosin-methylene blue agar. The $E$. coli colonies were counted and the proportion of haemolytic colonies to the total population was expressed as a percentage. To establish the serotype of the isolated colonies, five haemolytic and five nonhaemolytic $E$. coli colonies were picked at random from each blood agar plate and tested by slide agglutination. The haemolytic colonies were tested with antisera prepared against the haemolytic E. coli serotypes E145 and G7; the non-haemolytic colonies were tested with antisera prepared against the non-haemolytic E. coli strains Mac 111 and Mac 429.

Infection of piglets with $E$. coli strains E145 and Mac 111. On the 10th day after weaning all the piglets were deprived of water for $8 \mathrm{hr} ; 30 \mathrm{ml}$ of a 6-hr culture of $E$. coli E145 grown in trypticase broth was added to each 8 litres of drinking water. Piglets of groups A, B, $\mathrm{C}, \mathrm{D}$, and $\mathrm{AA}, \mathrm{BB}, \mathrm{CC}, \mathrm{DD}$, and $\mathrm{E}$ were allowed to drink this contaminated water. Another set of three piglets, called group F (offspring of control sow 2), was exposed to the nonhaemolytic $E$. coli Mac 111 by the same procedure.

Collection of serum and colostrum samples for antibody determination. Blood samples from sows were collected from the ear-veins whereas piglets were bled from the jugular vein. All samples were allowed to stand in the cold room at $4^{\circ} \mathrm{C}$ overnight to clot. The separated sera were collected, and centrifuged at $1035 \mathrm{~g}$, and the supernatants were stored at $-20^{\circ} \mathrm{C}$ until used.

Colostrum was collected from the sows immediately after farrowing and centrifuged at $1035 \mathrm{~g}$ to separate the fat. Fat-free colostrum was stored at $-20^{\circ} \mathrm{C}$ until used.

Passive cutaneous anaphylaxis test. Serum and colostrum samples from dams and serum samples from their piglets were examined by passive cutaneous anaphylaxis tests (Buxton and Thomlinson) for antibody against four strains of E. coli: the two haemolytic strains E145 and G7 and the two non-haemolytic strains Mac 429 and Mac 111 detailed in table II. None of these four $E$. coli strains showed any cross-reactions in tube agglutination tests. The amounts of antibody in piglet sera given in the tables are the average values for three animals on the basis of the following test. 
Extracts were prepared from strains E145, G7, Mac 429 and Mac 111 by the freezing and thawing technique of Erskine, Sojka and Lloyd (1957). Extracts were diluted with a 0.5 per cent. solution of Evans' blue to give a final antigen concentration of 1 in 10 . The tests were done on female albino guinea-pigs, each weighing 300-400 g. Each sample was tested in at least three guinea-pigs. After the abdomen had been shaved, $0 \cdot 1-\mathrm{ml}$ samples of pig serum or fat-free colostrum were injected intradermally with $26 \mathrm{G}$ hypodermic needles with intradermal-type bevels. Three hours later, $1 \mathrm{ml}$ of $E$. coli extract mixed with the Evans' blue was injected into the saphenous vein. The results were recorded $90 \mathrm{~min}$. later by measuring the diameter of the pale blue hyperaemic reactions in the skin; the following code was used: $-=$ no reaction, $t=$ doubtful reaction, $+=$ reaction diameter $4-7 \mathrm{~mm},++=$ $8-11 \mathrm{~mm},+++=12-15 \mathrm{~mm}$, and $++++=16-20 \mathrm{~mm}$. The degree of reaction observed is proportional to the amount of antibody present. The most important antibody in this reaction is probably IgG, although other classes may take part (Orange and Austen, 1971). Control tests to confirm that hyperaemia was not induced by either the antiserum or the antigenic extracts alone were performed by (i) injecting intravenously Evans' blue in saline into skin-sensitised guinea-pigs, and (ii) injecting saline intradermally into sensitised and antigen-challenged animals.

\section{RESULTS}

Observations on Escherichia coli in the faeces of dams and their offspring before weaning

There were no haemolytic $E$. coli in the faeces of any of the dams in the time-interval of 15 days before and 3 wk after parturition. This excluded the possibility that a natural infection with the haemolytic challenge strain could be passed from the dam to the offspring. Before weaning, all piglets passed nonhaemolytic $E$. coli in their faeces and none showed any signs of diarrhoea. None of the $E$. coli was of E145, G7, Mac 111 or Mac 429 serotype.

\section{The production of diarrhoea in piglets derived from normal sows}

Faecal samples of non-vaccinated piglets (groups D and DD), derived from normal sows 2 and 4 respectively, yielded no $E$. coli E145 before challenge. Although small numbers of serologically unidentified haemolytic $E$. coli were detected in faecal samples of piglets of group D, no diarrhoea was observed before challenge with E145 (fig. 1a). Within $48 \mathrm{hr}$ after exposure of piglets to $E$. coli E145, large numbers of this organism were detected in their faeces and continued to be isolated in the next 12-14 days (fig. $1 a$ and $b$ ). All the piglets had diarrhoea approximately 48-96 $\mathrm{hr}$ after challenge and this situation prevailed for approximately 12 days. The diarrhoea stopped when no more $E$. coli E145 was detected in the faecal specimens.

Vaccinated piglets (groups $\mathrm{C}$ and $\mathrm{CC}$ ), derived from these same normal sows 2 and 4 respectively, did not pass any $E$. coli $\mathrm{E} 145$ in their faeces before challenge. Piglets of group $\mathrm{C}$, however, excreted some unidentified haemolytic $E$. coli (fig. 1c), but this was not accompanied by diarrhoea. $E$. coli E145 could be detected in the faeces of piglets within $48 \mathrm{hr}$ after challenge and was isolated for the next 8-10 days (fig. $1 c$ and $d$ ). Diarrhoea started 48-96 hr after challenge and lasted for approximately 10 days. 

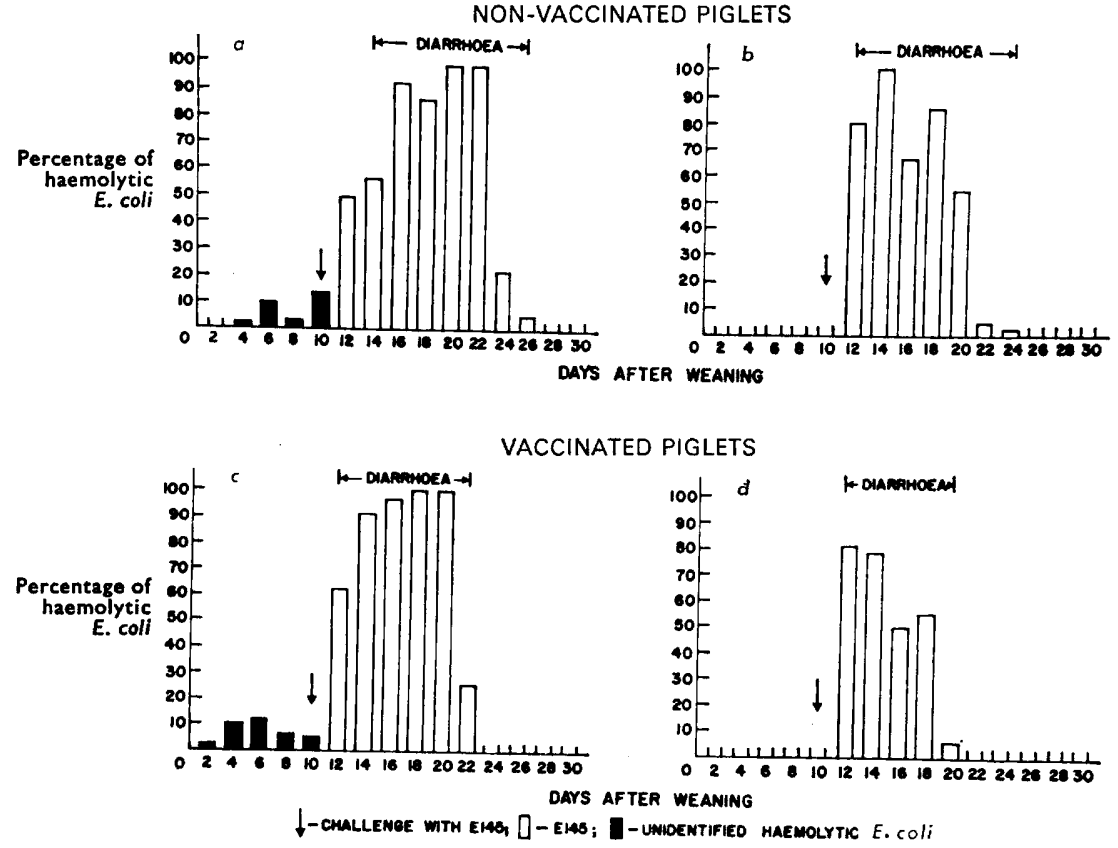

FIG. 1. - The proportion of haemolytic to total E. coli after infection with strain E145 in faecal samples of piglets derived from normal sows. Histograms $(a)$ and $(b)$ are for groups D and DD respectively. Histograms $(c)$ and $(d)$ are for groups $\mathrm{C}$ and $\mathrm{CC}$ respectively. Histograms $(a)$ and $(c)$ refer to the progeny of sow $2 ;(b)$ and $(d)$ refer to the progeny of sow 4.
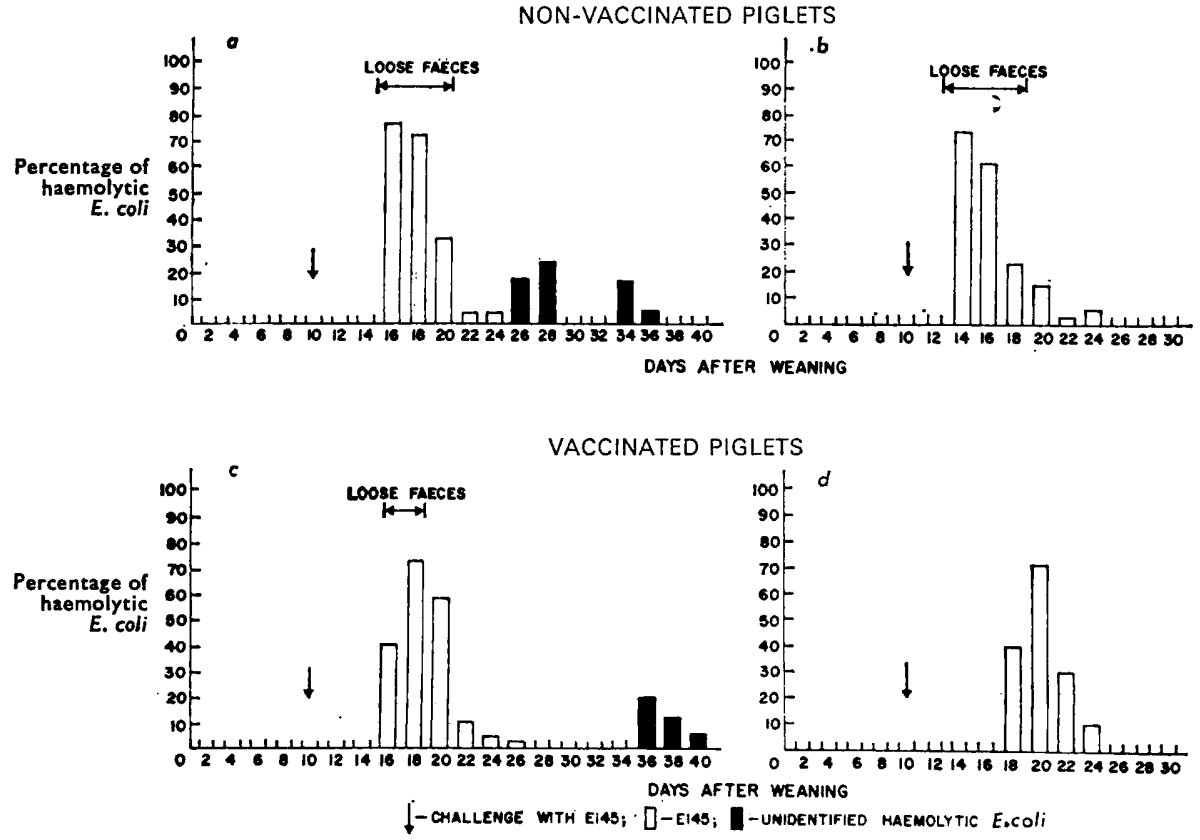

FIG. 2.-The proportion of haemolytic to total $E$. coli after infection with strain E145 in faecal samples of piglets derived from vaccinated sows. Histograms $(a)$ and $(b)$ are for groups B and BB respectively. Histograms $(c)$ and $(d)$ are for groups A and AA respectively. Histograms $(a)$ and $(c)$ refer to the progeny of sow $1 ;(b)$ and $(d)$ refer to the progeny of sow 3. 
The effects of challenge on piglets derived from the vaccinated sows

Before challenge with strain E145, no haemolytic $E$. coli were isolated from piglets of vaccinated sows. $E$. coli E145 appeared in the faeces of non-vaccinated piglets (groups B and BB) on the 4th or 6th day after challenge (fig. $2 a$ and $b$ ) and was isolated for the next 8-10 days. No severe diarrhoea occurred in any of the piglets, although loose faeces were passed intermittently for approximately 6 days starting 3-5 days after challenge.

\section{PASSIVELY IMMUNISED PIGLETS}

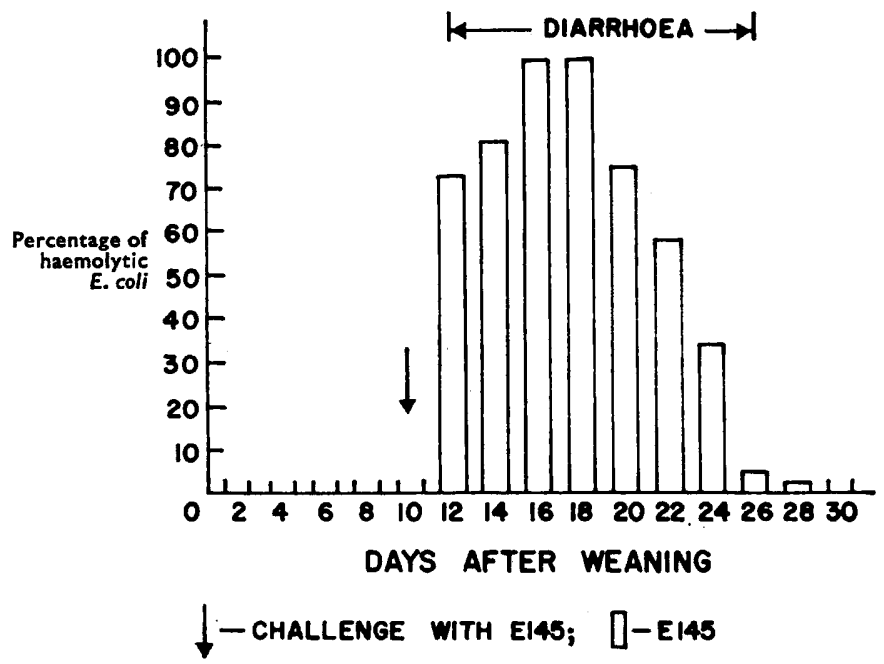

FIG. 3.-The proportion of haemolytic to total $E$. coli after infection with $\mathrm{E} 145$ in faecal samples of passively immunised piglets (group E) derived from sow 4.

$E$. coli E145 appeared in the faeces of vaccinated piglets (groups A and AA) on the 6 th or the 8 th day after challenge (fig. $2 c$ and $d$ ) and continued to be excreted in comparatively small numbers for 6-10 days. No diarrhoea was observed in any animal, although piglets of group $\mathrm{A}$, vaccinated with the formalin-killed vaccine, passed loose faeces for approximately 3 days. Piglets of group AA, given the formalin-killed vaccine emulsified in Freund's adjuvant, passed normal faeces throughout the period of observation.

The excretion of unidentified haemolytic $E$. coli starting on the 26th day after weaning (fig. $2 a$ and $c$ ) was not accompanied by diarrhoea. These organisms were probably " natural" contaminants in barn I where these animals were housed.

The production of diarrhoea in passively immunised piglets

Within $48 \mathrm{hr}$ after challenge with $E$. coli E145, diarrhoea started and large numbers of these organisms were detected in the faeces of passively immunised piglets of group E (fig. 3). The organism was excreted and diarrhoea lasted for approximately 14 days. 
Absence of diarrhoea in piglets exposed to a non-haemolytic strain of E. coli

$E$. coli strain Mac 111 was originally isolated from a piglet with colibacillosis, but its enteropathogenicity had not been proved. An attempt was therefore

TABLE III

Antibody levels in normal sows and their offspring

\begin{tabular}{|c|c|c|c|c|c|}
\hline \multirow{2}{*}{ Animals } & \multirow{2}{*}{$\begin{array}{l}\text { Sample and } \\
\text { time of sampling }\end{array}$} & \multicolumn{4}{|c|}{$\begin{array}{l}\text { Relative amount of antibody* } \\
\text { to } E \text {. coli strain }\end{array}$} \\
\hline & & E 145 & G 7 & Mac 111 & Mac 429 \\
\hline Sow 2 & $\begin{array}{l}\text { Serum } \\
20 \text { days before parturition } \\
24 \text { hr after parturition } \\
\text { Colostrum }\end{array}$ & $\begin{array}{c}+++ \\
++ \\
++\end{array}$ & $\begin{array}{l}++ \\
+ \\
+\end{array}$ & $\begin{array}{c}++ \\
+ \\
+\end{array}$ & $\begin{array}{c}+++ \\
+++ \\
+++\end{array}$ \\
\hline $\begin{array}{l}\text { Non-vaccinated } \\
\text { piglets of group D }\end{array}$ & $\begin{array}{l}\text { Serum } \\
14 \text { days old } \\
2 \text { days after challenge } \\
14 \text { days after challenge }\end{array}$ & $\begin{array}{c} \pm \\
\pm \\
++\end{array}$ & \pm & $\begin{array}{l} \pm \\
\cdots \\
\cdots\end{array}$ & $\begin{array}{c}+++ \\
\ldots \\
\ldots\end{array}$ \\
\hline $\begin{array}{l}\text { Vaccinated piglets } \\
\text { of group C }\end{array}$ & $\begin{array}{l}\text { Serum } \\
14 \text { days old ( } 7 \text { days after } \\
\text { vaccination) } \\
2 \text { days after challenge } \\
14 \text { days after challenge }\end{array}$ & $\begin{array}{c} \pm \\
\pm \\
+ \\
+\end{array}$ & $\begin{array}{l} \pm \\
- \\
-\end{array}$ & $\begin{array}{l} \pm \\
\cdots \\
\cdots\end{array}$ & $\begin{array}{c}+++ \\
\cdots \\
\cdots\end{array}$ \\
\hline Sow 4 & $\begin{array}{l}\text { Serum } \\
20 \text { days before parturition } \\
24 \text { hr after parturition } \\
\text { Colostrum }\end{array}$ & $\begin{array}{c}+++ \\
++ \\
+\end{array}$ & $\begin{array}{l} \pm \\
\pm \\
-\end{array}$ & $\begin{array}{l}\cdots \\
\cdots \\
\cdots\end{array}$ & $\bar{z}$ \\
\hline $\begin{array}{l}\text { Non-vaccinated } \\
\text { piglets of group DD }\end{array}$ & $\begin{array}{l}\text { Serum } \\
14 \text { days old } \\
2 \text { days after challenge } \\
14 \text { days after challenge }\end{array}$ & $\begin{array}{c}\stackrel{ \pm}{ \pm} \\
++\end{array}$ & $\begin{array}{l}- \\
-\end{array}$ & $\begin{array}{l}\cdots \\
\cdots \\
\cdots\end{array}$ & $\begin{array}{l}\overline{-} \\
-\end{array}$ \\
\hline $\begin{array}{l}\text { Vaccinated piglets } \\
\text { of group CC }\end{array}$ & $\begin{array}{l}\text { Serum } \\
14 \text { days old ( } 7 \text { days after } \\
\text { vaccination) } \\
2 \text { days after challenge } \\
14 \text { days after challenge }\end{array}$ & $\begin{array}{c} \pm \\
\pm \\
+ \\
+\end{array}$ & $\begin{array}{l}- \\
-\end{array}$ & $\begin{array}{l}\cdots \\
\cdots \\
\cdots\end{array}$ & $\begin{array}{l}- \\
-\end{array}$ \\
\hline Controls $\dagger$ & & - & - & - & - \\
\hline
\end{tabular}

* In this and subsequent tables, $-=$ no reaction; $t=$ doubtful reaction; $+=$ skin reaction 4-7 $\mathrm{mm}$ in diameter; $++=8-11 \mathrm{~mm} ;+++=12-15 \mathrm{~mm} ;++++=16-20 \mathrm{~mm}$.

+ For details see text.

made to induce diarrhoea with this strain in three non-vaccinated piglets (group F), who were the progeny of control sow 2.

E. coli Mac 111 was isolated within $48 \mathrm{hr}$ after oral challenge from all the faecal samples taken from these piglets. The strain continued to be present for the next 6 days. Although on several days Mac 111 was the only $E$. coli

J. MED. MICROBIOL.-VOL. 5 (1972) 
recovered from the faeces, there was no diarrhoea in these piglets during the period of observation.

Antibody levels in normal sows and their offspring

The data given in table III indicate that the amount and specificity of anti-E. coli antibodies differed greatly in the two non-vaccinated control sows.

TABLE IV

Antibody levels in vaccinated sows and their offspring

\begin{tabular}{|c|c|c|c|c|c|}
\hline \multirow{2}{*}{ Animals } & \multirow{2}{*}{$\begin{array}{l}\text { Sample and } \\
\text { time of sampling }\end{array}$} & \multicolumn{4}{|c|}{$\begin{array}{l}\text { Relative amount of antibody* } \\
\text { to } E \text {. coli strain }\end{array}$} \\
\hline & & E 145 & G 7 & Mac 111 & Mac 429 \\
\hline Sow 1 & $\begin{array}{l}\text { Serum } \\
20 \text { days before parturition } \\
24 \mathrm{hr} \text { after parturition } \\
\text { Colostrum }\end{array}$ & $\begin{array}{c}++ \\
+++ \\
\cdots\end{array}$ & $\begin{array}{c}++ \\
++ \\
\cdots\end{array}$ & $\begin{array}{l}\cdots \\
\cdots\end{array}$ & $\begin{array}{c}+++ \\
+++ \\
\cdots\end{array}$ \\
\hline $\begin{array}{l}\text { Non-vaccinated } \\
\text { piglets of group B }\end{array}$ & $\begin{array}{l}\text { Serum } \\
14 \text { days old } \\
6 \text { days after challenge } \\
16 \text { days after challenge }\end{array}$ & $\begin{array}{c}+ \\
++ \\
++\end{array}$ & $\begin{array}{l}\overline{ \pm} \\
\pm\end{array}$ & $\begin{array}{l}- \\
\cdots \\
\cdots\end{array}$ & $\begin{array}{l}+ \\
\cdots \\
\cdots\end{array}$ \\
\hline $\begin{array}{l}\text { Vaccinated piglets } \\
\text { of group A }\end{array}$ & $\begin{array}{l}\text { Serum } \\
14 \text { days old ( } 7 \text { days after } \\
\text { vaccination) } \\
6 \text { days after challenge } \\
16 \text { days after challenge }\end{array}$ & $\begin{array}{c}t \\
++ \\
+++t\end{array}$ & $\begin{array}{l}- \\
\pm \\
\pm\end{array}$ & $\begin{array}{l}- \\
\cdots \\
\cdots\end{array}$ & $\begin{array}{l}+ \\
\cdots \\
\cdots\end{array}$ \\
\hline Sow 3 & $\begin{array}{l}\text { Serum } \\
20 \text { days before parturition } \\
24 \mathrm{hr} \text { after parturition } \\
\text { Colostrum }\end{array}$ & $\begin{array}{c}++ \\
+++ \\
++\end{array}$ & $\begin{array}{l} \pm \\
\pm \\
\pm\end{array}$ & $\begin{array}{l}\cdots \\
\cdots \\
\cdots\end{array}$ & $\begin{array}{l}\bar{z} \\
-\end{array}$ \\
\hline $\begin{array}{l}\text { Non-vaccinated } \\
\text { piglets of group BB }\end{array}$ & $\begin{array}{l}\text { Serum } \\
14 \text { days old } \\
4 \text { days after challenge } \\
16 \text { days after challenge }\end{array}$ & $\begin{array}{c}+ \\
+ \\
++\end{array}$ & $\bar{z}$ & $\begin{array}{l}\cdots \\
\cdots \\
\cdots\end{array}$ & $\bar{z}$ \\
\hline $\begin{array}{l}\text { Vaccinated piglets } \\
\text { of group AA }\end{array}$ & $\begin{array}{l}\text { Serum } \\
14 \text { days old (7 days after } \\
\text { vaccination) } \\
8 \text { days after challenge } \\
16 \text { days after challenge }\end{array}$ & $\begin{array}{c}++ \\
++ \\
+++\end{array}$ & $\begin{array}{l}- \\
-\end{array}$ & $\begin{array}{l}\cdots \\
\cdots \\
\cdots\end{array}$ & $\begin{array}{l}- \\
-\end{array}$ \\
\hline Controls $\dagger$ & & - & - & - & - \\
\hline
\end{tabular}

* See footnote to table III.

$\dagger$ For details see text.

Whereas sow 2 had fairly high serum and colostrum antibody levels against all four strains tested, sow 4 had measurable antibody against $E$. coli E145 only.

There was hardly any $E$. coli antibody in the sera of piglets of groups CC and 
DD before challenge with E145; piglets of groups C and D, however, showed a fairly high level of antibody against the non-haemolytic strain Mac 429. An increase in antibody against $E$. coli E145 was detected in all piglet sera 14 days after challenge with this strain. Hardly any difference in antibody levels was observed between vaccinated piglets and the non-vaccinated controls.

\section{Antibody levels in vaccinated sows and their offspring}

The general levels and variety of anti-E. coli antibodies in the sera and colostrum of sows in barn II differed greatly from those of sows in barn I (tables III and IV). Whereas sows 1 and 2 had antibodies to all four

TABLE V

Serum antibody levels in passively immunised piglets

\begin{tabular}{|c|c|c|c|c|}
\hline \multirow{2}{*}{ Animals } & \multirow{2}{*}{ Time of sampling } & \multicolumn{3}{|c|}{$\begin{array}{l}\text { Relative amount of antibody* } \\
\text { to } E \text {. coli strain }\end{array}$} \\
\hline & & E 145 & G 7 & Mac 429 \\
\hline $\begin{array}{l}\text { Piglets of group E } \\
\text { (offspring of sow 4) }\end{array}$ & $\begin{array}{l}\text { Before passive immunisation } \\
2 \text { days after passive immunisation } \\
\text { and challenge } \\
20 \text { days after challenge }\end{array}$ & $\begin{array}{c} \pm \\
\pm \\
+++\end{array}$ & $\begin{array}{l}- \\
-\end{array}$ & $\begin{array}{l}- \\
-\end{array}$ \\
\hline Controls $\dagger$ & & - & - & - \\
\hline
\end{tabular}

* See footnote to table III.

$\dagger$ For details see text.

antigens, sows 3 and 4 had antibodies to E145 only. An increase in antibody against $E$. coli E145 was observed in serum samples of sows after vaccination (table IV). In general there was a decrease in the levels of antibody to the other three strains after parturition (tables III and IV).

The serum from vaccinated piglets (groups $\mathrm{A}$ and $\mathrm{AA}$ ) and non-vaccinated piglets (groups B and BB) from these vaccinated dams showed antibody against E. coli E145 before challenge with this strain (table IV); this was not the case with the piglets derived from normal sows (table III). The antibody level against this strain increased soon after challenge, reaching high levels 16 days later.

\section{Antibody levels in passively immunised piglets}

The antibody levels against $E$. coli E145 in passively immunised piglets were similar to those of piglets derived from the control sows (table V). Antibody was not detected in these animals before or 2 days after passive immunisation. High antibody levels were observed 20 days after oral challenge with E. coli $\mathrm{E} 145$. 


\section{DISCUSSION}

The association of enteric colibacillosis in piglets with certain serotypes of $E$. coli has been fairly well established (Gay, 1965; Sojka, 1965; Nielsen, Moon and Roe, 1968). The fact that a large percentage of enteropathogenic $E$. coli strains are haemolytic led to the recognition of potentially pathogenic strains. The haemolysins of these organisms are not, however, considered to be responsible for pathogenicity (Smith, 1963) and our present results confirm the reports of other investigators (Campbell, 1959; Sojka, Lloyd and Sweeney, 1960; Smith; Arbuckle, 1968a) that the isolation of haemolytic E. coli is not necessarily associated with diarrhoea.

In order to prove that a strain of $E$. coli is enteropathogenic it is necessary not only to show an epidemiological association of the organism, but also to demonstrate its ability to produce a positive "gut-loop reaction" or enteric colibacillosis. Although the Mac 111 strain of E. coli was isolated from a piglet in a field outbreak of colibacillosis, it failed to produce the disease experimentally. Large numbers of this organism were isolated from the faeces of infected but apparently healthy piglets for 6 days; the finding indicates that this particular $E$. coli strain may not have been the cause of diarrhoea in that outbreak or that the strain altered in vitro. These observations are in accord with those of Gay (1971), who cautioned against placing too much significance on any $E$. coli isolated from an animal with diarrhoea.

Chopra et al. (1964a) observed that during a natural outbreak of enteritis one enteropathogenic strain of $E$. coli may replace another during continuous diarrhoea. A similar replacement of dominant serotypes of non-pathogenic $E$. coli has been reported by Barnum (1971) in healthy piglets. Our results show that in piglets experimentally infected with $E$. coli E145, diarrhoea paralleled the isolation of this organism in the faeces. The enteropathogenic organism was replaced gradually by other $E$. coli strains and the diarrhoea stopped. Our findings agree with those of Smith and Jones (1963) who also reported an association between enteropathogenic $E$. coli and colibacillosis in conventionally reared pigs. These results are, however, in contrast with those of Kohler (1967) and Miniats et al. (1970), who did not find this association in gnotobiotic pigs.

E. coli E145 was isolated for 8-14 days from piglets derived from normal sows and for only 6-10 days from piglets derived from vaccinated sows. Diarrhoea accompanied the isolation of E145 from the piglets of non-vaccinated sows, whereas piglets from vaccinated sows had either loose or normal faeces. E. coli E145 appeared, on the average, 4 days later in the faeces of piglets from the vaccinated sows than in the faeces of piglets from the control sows. The sow given vaccine emulsified in Freund's complete adjuvant conferred a better protection against diarrhoea to her offspring than the sow vaccinated with the formalin-killed vaccine alone. This agrees with the observations of Gay, McKay and Barnum (1964), who reported that a formalin-killed oil-adjuvant vaccine was capable of controlling and preventing outbreaks of colibacillosis in calves. 
Vaccination of piglets alone proved to be of no value in either preventing the establishment of $E$. coli E145 in the gut or in appreciably shortening the time of diarrhoea. Intramuscular vaccination was expected to induce a rise in the serum antibody titre of the vaccinated piglets; however, no great difference was observed between these and the non-vaccinated animals. This failure could be attributed to the early age at which the piglets were given this antigen, since the age at which pigs first produce antibody appears to vary (Hoerlein, 1957; Brown et al., 1961; Aiken and Blore, 1964); there is also the possibility that the immunoglobulins produced by these animals were not detected by our tests. The antibody detected by us in the PCA reaction was probably IgG (Orange and Austen, 1971). E. coli, however, does not extensively or preferentially stimulate antibodies of this immunoglobulin class. It has been reported that antibodies to Gram-negative bacteria are associated with IgM (Michael and Rosen, 1963). This has been confirmed by Kohler and Bohl (1966), who demonstrated that bactericidal and haemagglutinating antibody to $E$. coli in pigs could be inactivated by mercaptoethanol treatment. Cohen and Norins (1966), however, found by fluorescent antibody techniques that natural antibodies to $E$. coli in human serum are present in the IgM, IgG and IgA fractions. These authors suggest that anti-E. coli IgG is not detected because of its inefficiency in agglutination, haemagglutination, bacteriolytic and haemolytic activity or opsonisation tests, which are the ones commonly used. It has been shown recently by the antiglobulin haemagglutination test that incomplete antibody to $E$. coli somatic antigens is in the IgG fraction in pig serum (Porter and Kenworthy, 1969) and in pig colostrum (Porter, Noakes and Allen, 1970). The latter authors have also demonstrated that colostral antibody in the first 2 days after parturition is largely IgG. Thus, it seems that $E$. coli can induce the production of antibodies belonging to various immunoglobulin classes, which are detected to different degrees by the various tests used.

It is of interest that both non-vaccinated sows had detectable anti-E. coli E145 antibodies in their serum and colostrum and despite this, diarrhoea occurred in their offspring. Since no haemolytic coliform organisms were isolated from faecal specimens of these two sows before farrowing, it is assumed that these organisms were part of the transient flora at some time previous to testing and stimulated production of antibacterial antibody during their stay in the gut. It was observed that antibody levels decreased in serum after parturition, and one might assume that the same decrease could have occurred in the colostrum. Lack of protection against diarrhoea could then be explained by an insufficient amount of homologous antibody being passed to the offspring. This suggestion is supported by the fact that serum antibody was not detected in 14-day-old non-vaccinated piglets derived from normal sows, whereas nonvaccinated piglets derived from vaccinated sows had antibody against $E$. coli E145 at this time. This suggests that the vaccinated sows probably passed large amounts of antibody to their offspring, since piglets cease to absorb immunoglobulins after the first 24-36 hr of life (Lecce and Morgan, 1962), and passively acquired antibody falls to very low levels during the first 2-3 wk of life (Sharpe, 1965; Arbuckle, 1968b). Circulating antibody in piglets before 
challenge was associated in this study with either very mild diarrhoea or no diarrhoea at all.

Shreeve and Thomlinson (1970) propose that colostral antibody induced by vaccination may either sensitise or protect, depending on the relative amounts transferred to the piglet. If the amount of antibody is large, the offspring will be protected; if, on the other hand, only small amounts of antibody are passed, these will hypersensitise the intestinal tract of the piglet, leading to local anaphylaxis and scouring when the animals are challenged with $E$. coli. The scouring in the progeny of our two non-vaccinated sows could have been due to this phenomenon, since both of them had a small amount of anti-E. coli E145 antibody in their colostrum.

Serum antibody concentrations reached high levels in all infected piglets 14 to 16 days after challenge and this coincided with the end of diarrhoea. It has been shown in man that, although the greatest concentration of antibody is in the gut after oral immunisation with attenuated viruses, or living or dead bacteria, specific antibodies can also be detected in the serum (Freter, 1962; Ogra and Karzon, 1969). If colibacillosis in pigs presents an analogous situation, then detection of antibody in the serum implies that there may be a larger concentration present in the gut where it could combat the infection. In recent years, evidence has accumulated to suggest that secretory $\operatorname{IgA}$ is the principal immunoglobulin in all mucous secretions (Tomasi and Bienenstock, 1968). The possible role of $\operatorname{IgA}$ in the immunological defence of the pig against colibacillosis has been suggested by Porter and Noakes (1969), and Porter et al. (1970), since $E$. coli antibodies in the gut of a normal pig are in the IgA fraction.

In our experiment with passive immunisation, parenterally introduced serum from a vaccinated sow failed to protect piglets against diarrhoea or to reduce the length of time that $E$. coli E145 remained in the gut. Assuming that a suitable amount of antiserum was injected, our results do not indicate that these antibodies injected parenterally play a direct role in preventing or limiting diarrhoea in piglets.

This observation agrees with those of Kohler (1967) and Arbuckle (1968b), who showed that detectable specific serum antibody does not protect the pig from enteric diarrhoea; Kohler (1967) and Miniats et al. (1970) showed, however, that diarrhoea could be prevented if immune serum was given orally to experimentally infected gnotobiotic piglets. Thus, in the present study, reduction in diarrhoea of the piglets that were derived from the vaccinated sows could probably be attributed to locally acting antibody acquired from the dam.

Recent evidence (Kohler, 1968; Kohler and Cross, 1969) indicates that scours in piglets may be produced by enterotoxins in the absence of viable enteropathogenic $E$. coli. It would be of interest to determine whether antienterotoxic sera protect pigs against enteric colibacillosis.

\section{SUMMARY}

The efficacy of vaccination against enteric colibacillosis was evaluated in conventionally reared, artificially infected early weaned piglets. 
Successful infection with profuse diarrhoea was produced with haemolytic E. coli E145 administered orally to piglets derived from normal sows. Active immunisation of the piglets soon after birth with strain E145 did not protect them from diarrhoea when they were challenged with the same organism. Passive immunisation of piglets with parenterally injected immune serum from a sow vaccinated with strain E145 also failed to protect. On the other hand, no diarrhoea was induced in piglets from sows vaccinated with the challenge organism, although intermittent loose faeces were observed for a relatively short time.

Large numbers of $E$. coli E145 were excreted 2 days after oral challenge in the faeces of the offspring of normal sows. In contrast, this organism appeared, on the average, 4 days later in the faeces of piglets derived from the vaccinated sows; it was excreted for a shorter time and in smaller numbers.

Circulating antibodies against $E$. coli E145 were detected by passive cutaneous anaphylaxis before challenge only in piglets derived from vaccinated sows. High serum antibody levels against E145 were detected in all piglets after challenge, irrespective of whether they had actual diarrhoea or not.

A non-haemolytic $E$. coli strain Mac 111, isolated from a piglet with enteric colibacillosis, failed to induce this disease experimentally.

We are grateful to Dr A. C. Blackwood and Dr H. C. Gibbs for valuable discussions throughout this work and for providing space for the experimental animals. This work was supported with funds provided by the Quebec Agriculture Research Council.

\section{REFERENCES}

AIKEN, J. M., AND BLORE, IDA C. 1964. Immunology of newborn pigs: response to lapinized hog cholera virus in colostrum-deprived and suckling pigs. Amer. J. Vet. Res., 25, 1134.

ARBUCKLE, J. B. R. 1968a. The distribution of certain Escherichia coli strains in pigs and their environment. Br. Vet. J., 124, 152.

ARBUCKLe, J. B. R. 1968b. The occurrence of Escherichia coli somatic antibody in pig serum, colostrum and milk and an investigation of its possible significance in immunity. Br. Vet. J., 124, 273.

BARNUm, D. A. 1971. The control of neonatal colibacillosis of swine. Ann. N. Y. Acad. Sci., 176, 385.

Brown, H., Speer, V. C., QuinN, L. Y., Hays, V. W., and Catron, D. V. 1961. Studies on colostrum-acquired immunity and active antibody production in baby pigs. J. Anim. Sci., $20,323$.

Bunch, R. J., Speer, V. C., Hays, V. W., Hawbaker, J. H., and Catron, D. V. 1961. Effects of copper sulfate, copper oxide and chlortetracycline on baby pig performance. J. Anim. Sci., 20, 723.

Buxton, A., AND Thomlinson, J. R. 1961. The detection of tissue-sensitizing antibodies to Escherichia coli in oedema disease, haemorrhagic gastro-enteritis and in normal pigs. Res. Vet. Sci., $2,73$.

Cameron, H. S. 1942. Field investigations on sulfaguanidine in swine enteritis. Cornell Vet., 32, 1.

Campbell, S. G. 1959. Studies on strains of haemolytic Escherichia coli isolated from normal swine after weaning. Vet. Rec., 71, 909.

Charter, Ruth E., AND TAYlor, JoAN 1952. Cultural and serological reactions of Bact. coli isolated from babies. J. Path. Bact., 64, 729. 
Chopra, S. L., Blackwood, A. C., ANd Dale, D. G. 1964a. Enteritis of early weaned pigs. I. Enteropathogenic Escherichia coli. Canad. J. Comp. Med., 28, 239.

Chopra, S. L., Blackwood, A. C., AND Dale, D. G. $1964 b$. Enteritis of early weaned pigs. II. Pathogenesis. Canad. J. Comp. Med., 28, 272.

COHEN, I. R., AND NoRINS, L. C. 1966. Natural human antibodies to Gram-negative bacteria: immunoglobulins G, A and M. Science, N.Y., 152, 1257.

ERSKINE, R. G., SOJKA, W. J., AND LLOYD, M. K. 1957. The experimental reproduction of a syndrome indistinguishable from oedema disease. Vet. Rec., 69, 301.

FreTER, R. 1962. Detection of coproantibody and its formation after parenteral and oral immunization of human volunteers. J. Infect. Dis., 111, 37.

GAY, C. C. 1965. Escherichia coli and neonatal disease of calves. Bact. Rev., 29, 75.

GAY, C. C. 1971. Problems of immunization in the control of Escherichia coli infection. Ann. N.Y. Acad. Sci., 176, 336.

GaY, C. C., MCKaY, K. A., AND Barnum, D. A. 1964. Studies on colibacillosis of calves. I. The antibody acquired by calves as the result of vaccination of the dam. Canad. Vet. J., 5, 248.

Gordon, W. A. M., AND LuKe, D. 1958. Gastro-enteritis in young piglets associated with Escherichia coli. Vet. Rec., 70, 542.

HoERLEIN, A. B. 1957. The influence of colostrum on antibody response in baby pigs. J. Immun., 78, 112.

Jones, J. E. T., Sellers, K. C., ANd Smith, H. W. 1962. The evaluation of live and dead Escherichia coli vaccines administered to the pregnant female in the prevention of scouring (diarrhoea) in piglets. Vet. Rec., 74, 202.

KeRNKAMP, H. C. H., AND RoEPKe, M. H. 1943. Sulfaguanidine in the treatment of infectious enteritis in swine. Amer. J. Vet. Res., 4, 3.

KOHLER, E. M. 1967. Studies of Escherichia coli in gnotobiotic pigs. V. Evaluation of the effects of oral and parenteral administration of immune serum. Canad.J. Comp. Med., 31, 283.

KOHLER, E. M. 1968. Enterotoxic activity of filtrates of Escherichia coli in young pigs. Amer. J. Vet. Res., 29, 2263.

KoHLER, E. M., AND BoHL, E. H. 1966. Studies on Escherichia coli in gnotobiotic pigs. II. The immune response. Canad. J. Comp. Med., 30, 169.

Kohler, E. M., AND Cross, R. F. 1969. Studies of Escherichia coli in gnotobiotic pigs. VI. Effects of feeding bacteria-free filtrates of broth cultures. Canad.J. Comp. Med., 33, 173.

LECCE, J. G., AND MORGAN, D. O. 1962. Effect of dietary regimen on cessation of intestinal absorption of large molecules (closure) in the neonatal pig and lamb. J. Nutr., 78, 263.

Michael, J. G., AND Rosen, F. S. 1963. Association of " natural " antibodies to Gramnegative bacteria with the $\gamma_{1}$ macroglobulins. J. Exp. Med., 118, 619.

Miniats, O. P., Mrtchell, L., AND BaRNUM, D. A. 1970. Response of gnotobiotic pigs to Escherichia coli. Canad. J. Comp. Med., 34, 269.

Moon, H. W. 1969. Enteric colibacillosis in the newborn pig: problems of diagnosis and control. J. Amer. Vet. Med. Assoc., 155, 1853.

Nielsen, N. O., MoON, H. W., AND Roe, W. E. 1968. Enteric colibacillosis in swine. $J$. Amer. Vet. Med. Assoc., 153, 1590.

Ogra, P. L., AND Karzon, D. T. 1969. Distribution of poliovirus antibody in serum, nasopharynx and alimentary tract following segmental immunization of lower alimentary tract with poliovaccine. J. Immun., 102, 1423.

Orange, R. P., AND AUSTEN, K. F. 1971. Chemical mediators of immediate hypersensitivity. In Immunobiology, ed. by R. A. Good and D. W. Fischer, Stamford, Conn., p. 115.

Porter, P., AND KeNWORTHY, R. 1969. Macroglobulin antibodies in the natural immune response to endotoxin in Escherichia coli associated enteritis in the weaned pig. J. Comp. Path., 79, 553.

Porter, P., AND Noakes, D. E. 1969. Immunoglobulins in sow mammary secretions throughout lactation and their significance as anti- (Escherichia coli) antibodies to the young pig. Biochem. J., 113, 6P. 
Porter, P., Noakes, D. E., And Allen, W. D. 1970. Secretory IgA and antibodies to Escherichia coli in porcine colostrum and milk and their significance in the alimentary tract of the young pig. Immunology, 18, 245.

Sharpe, Heather B. A. 1965. A study of antibody levels in the young pig. Res. Vet. Sci., 6, 490.

Shreeve, B. J., AND Thomlinson, J. R. 1970. Hypersensitivity in young piglets: its relation to the pathogenesis of Escherichia coli disease. J. Med. Microbiol., 3, 377.

Sмrтн, H. W. 1963. The haemolysins of Escherichia coli. J. Path. Bact., 85, 197.

SMITH, H. W., AND JoNES, J. E. T. 1963. Observations on the alimentary tract and its bacterial flora in healthy and diseased pigs. J. Path. Bact., 86, 387.

SoJKA, W. J. 1965. Escherichia coli in domestic animals and poultry. Review series No. 7, Commonwealth Bureau of Animal Health, Farnham Royal, p. 118.

SoJKa, W. J., LlOYd, M. K., AND SWEEnEY, E. J. 1960. Escherichia coli serotypes associated with certain pig diseases. Res. Vet. Sci., 1, 17.

Tomasi, T. B., JR, AND Bienenstock, J. 1968. Secretory immunoglobulins. Adv. Immun., 9, 1.

Whitehair, C. K., Grummer, R. H., Phillips, P. H., Bohstedt, G., and McNutt, S. H. 1948. Gastroenteritis in pigs. Cornell Vet., 38, 24. 